\title{
Seed quality and crop performance of soybeans submitted to different forms of treatment and seed size ${ }^{1}$
}

\author{
Cristiane Moi Soares², Marcos Paulo Ludwig ${ }^{2 *}$, Claudia Moi Soares Rother ${ }^{3}$, \\ Leticia Decarli ${ }^{2}$
}

\begin{abstract}
The objective of this work was to evaluate the effect of different grain sizes and treatments in the physiological quality of seeds and performance of soybean cultures. The object of analysis were seeds from the cultivars Monsoy 5730 IPRO and Monsoy 5947 IPRO, sized 5.5 and $6.5 \mathrm{~mm}$. The industrial seed treatment was carried out in lot equipment, with the products cyantraniliprole, thiamethoxam, metalaxyl, thiabendazole, and a combination of fludioxonil + polymer + talc. The conventional treatment was performed with the products cyantraniliprole, thiamethoxam, metalaxyl, thiabendazole, and fludioxonil. Part of the seeds was kept untreated (control). The experiment used a randomized block design, with four replications. The parameters assessed include the moisture content measurement, seed coating, germination, first germination count, field emergence, survival rate, and grain yield (right after the seed treatment and after 45 days of storage). The industrial treatment method produced a better seed coating. As for seed size, it had no effect on quality or grain yield. Last, the treated seeds presented the best results for emergence in field, while the industrial treatment achieved the highest productivity.
\end{abstract}

Index terms: Glycine max, grain yield, industrial seed treatment, vigor.

\section{Qualidade e desempenho da cultura da soja submetida a diferentes formas de tratamento e tamanho de sementes}

\begin{abstract}
RESUMO - O objetivo deste trabalho foi avaliar o efeito de diferentes tamanhos de sementes e formas de tratamento a que elas são submetidas na qualidade fisiológica e desempenho da cultura da soja. Foram utilizadas sementes das cultivares Monsoy 5730 IPRO e Monsoy 5947 IPRO, com tamanhos de 5,5 e 6,5 mm. O tratamento industrial foi realizado em um equipamento de bateladas, com os produtos ciantraniliprole, tiametoxam, metalaxil, tiabendazol e a combinação fludioxonil + polímero + talco. O tratamento convencional foi realizado com os produtos ciantraniliprole, tiametoxam, metalaxil, tiabendazol e fludioxonil. Parte das sementes também foi mantida sem tratamento (controle). O delineamento utilizado foi de blocos ao acaso com quatro repetições. Foram avaliados o grau de umidade, cobertura de sementes, germinação, primeira contagem, emergência em campo, sobrevivência e produtividade de grãos em duas épocas de semeadura (após o tratamento e 45 dias depois). O método de tratamento industrial apresentou melhor cobertura de sementes. $O$ tamanho de sementes não causa efeito na produtividade e qualidade fisiológica das sementes. As sementes tratadas possuem melhor emergência em campo, e o tratamento industrial resulta em maior produtividade.
\end{abstract}

Termos para indexação: Glycine max, produtividade de grãos, tratamento industrial de sementes, vigor.

\section{Introduction}

The area cultivated with soybean in Brazil has increased by $3.4 \%$, going from $33,909.4$ thousand hectares $(2016 / 2017)$ to $35,046.5$ thousand $(2017 / 2018)$. The estimated production

${ }^{1}$ Submitted on 08/03/2018. Accepted for publication on 10/26/2018. ${ }^{2}$ Curso de Agronomia, IFRS - Campus Ibirubá, Caixa Postal 121, 98200-000 Ibirubá, RS, Brasil. should reach 113,024.60 thousand tons, in contrast with the $114,075.30$ thousand from the previous harvest, which represents a decrease of $0.9 \%$ (CONAB, 2018). These data evidence the essential role played by soybean culture in the Brazilian socio-economic scenario, as well as it emphasizes

${ }^{3}$ COTRIJAL, 99.470-000 - Não-Me-Toque, RS, Brasil.

*Corresponding author < marcos.ludwig@ibiruba.ifrs.edu.br> 
the importance of using management techniques, in order to improve productivity.

Since soybean is the primary national agricultural product for exportation, studies that contribute to maximizing the yield are fundamental. Quality enhancement and cost reduction in the controlling of plagues and diseases are also crucial aspects in sustaining the national production chain (Burssolaro et al., 2011).

The constant necessity of perfecting the management of this culture involves the employment of methods that can potentially improve its field performance. Therefore, the usage of treated seeds is directly related to high productivity (Ludwig et al., 2015).

New enhancement technologies are the subject of several studies, once optimizing production resources is a continuous necessity. In this context, the treatment of seeds is an alternative to protect cultures against diseases and insects, especially during the early cultivation stages, thus promoting vigor and a better establishment of the plants. These treatments comprehend the application of chemical or biological agents to the seeds, in order to suppress, control or repel pathogens, insects or other plagues (ABRASEM, 2015).

It is worth remarking that seed treatments are currently transitioning to an "on-farm" mode, instead of the usual industrial methods, which are generally costly. This new approach comes from the necessity of obtaining high-quality performances, and also from the increasing environmental awareness. Treatments Seed Industrial (TSI) stand on three basic principles: high-technological equipment, modern products, and optimized facilities (Ludwig, 2017b). That being the case, there is a growing demand for continued studies that enable the evaluation of these treatments, focusing at their effects on the productive soybean performance.

The use of technologies to augment productivity led to the classification of soybean seeds as for their diameter, an important aspect to be considered by farmers and seedproducing companies. Such procedures result in a product not only more homogeneous, which facilitates the mechanical sowing and the establishment of plant stands, but also more commercially appealing (Peske and Labbé, 2012). Nonetheless, variations in grain size produce distinct values for the features weight of thousand seeds and area covered by the seeds. These factors may affect the quality of treatments (Ludwig, 2017a).

The dosage of the products usually does not variate, and it is defined by the weight (mL.100 $\mathrm{kg}^{-1}$ of seeds). So, small seeds tend to receive less product than large ones, as there are more grains per unit of weight (which also implies that a larger sowing area can be covered with a given mass of grains). That being the case, although the plant specimen ought to be protected during application, if seed dimensions vary, the dosage should be adjusted. Otherwise, the small ones might not get enough protection (Nunes, 2016).

Once in-depth studies approaching both seed size and treatment methods are still scarce, the present work aimed at evaluating the impact of these two factors on the physiological quality of soybean seeds and performance of the crops.

\section{Material and Methods}

The experiments were carried out during the 2016/2017 harvest, in the physiographic region of Planalto Médio (central plateau), in the Brazilian state of Rio Grande do Sul. The local climate is Cfa (humid subtropical) (Moreno, 1961), and the soil is classified as typical dystroferric Red Latosol (Embrapa, 2013). The area is located $416 \mathrm{~m}$ above sea level, at a latitude of $28^{\circ} 37^{\prime} 39^{\prime \prime} \mathrm{S}$ and longitude of $53^{\circ} 05^{\prime} 23^{\prime \prime} \mathrm{W}$.

Seeds sieve-graded 5.5 and $6.5 \mathrm{~mm}$ diameter were used. They belonged to the cultivars Monsoy 5730 IPRO and Monsoy 5947 IPRO. The former has a 5.7 maturation cycle, indeterminate growth behavior, and resistance to lodging; whereas the latter has a 5.9 maturation cycle, and shows indeterminate growth behavior and moderate resistance to lodging. They were all submitted to industrial and conventional treatments, with the respective controls (untreated).

The treatments were applied to the seeds according to the technical recommendations. The Treatments Seed Industrial (TSI) and the Conventional Seed Treatment (CST) followed the guidelines proposed by Freiberg et al. (2017), in which the TSI was conducted with proper equipment, and the CSI was performed in plastic bags.

The following products were used in the present study:

TSI: Fortenza $600 \mathrm{FS}^{\circledR}$ (cyantraniliprole) $0.8 \mathrm{~mL} \cdot \mathrm{kg}^{-1}$, Cruiser $^{\circledR} 350$ FS (thiamethoxam) $2.5 \mathrm{~mL} \cdot \mathrm{kg}^{-1}$, Maxim Advanced $^{\circledR}$ (metalaxyl, thiabendazole, and fludioxonil) 1.0 mL. $\mathrm{kg}^{-1}$, polymer DISCO AG CLEAR L-323 ${ }^{\circledR} 1.0 \mathrm{~mL} . \mathrm{kg}^{-1}$, and talc $^{\circledR} 1.5 \mathrm{~mL} \cdot \mathrm{kg}^{-1}$. This treatment was performed in a Momesso Arktos Africa L40K ${ }^{\circledR}$ equipment, with a capacity of $15 \mathrm{~kg}$. Each lot contained $2.5 \mathrm{~kg}$ of seeds.

CST: Fortenza $600 \mathrm{FS}{ }^{\circledR}$ (cyantraniliprole) $0.8 \mathrm{~mL} \cdot \mathrm{kg}^{-1}$, Cruiser $^{\circledR} 350$ FS (thiamethoxam) $2.5 \mathrm{~mL} \cdot \mathrm{kg}^{-1}$, Maxim Advanced ${ }^{\circledR}$ (metalaxyl, thiabendazole, and fludioxonil) $1.0 \mathrm{~mL} \cdot \mathrm{kg}^{-1}$. This treatment used plastic bags, in which the seeds were shaken until they were fully coated.

The seed analyses were conducted immediately after the treatments and 45 days afterward. Meanwhile, they were stored in uncontrolled ambient conditions.

The moisture content analysis utilized two subsamples per replication. Each was placed inside an oven at a constant temperature of $105{ }^{\circ} \mathrm{C}$ for 24 hours, and then 
weighed (Brasil, 2009). Seed coating was assessed visually by the intensity of the pigmentation produced by the polymer or coloring of the products applied. For this purpose, a Burris (s.d.) scale ranging from 0 to 10 was employed, in which the lowest value implied in product-free seeds, whereas the highest one indicated a full coating. For these tests, ten seeds were randomly picked from each moisture content group (Ludwig et al., 2011a).

The quality of the seeds was appraised through the germination, first count, and field emergence tests. The germination test was conducted by sowing four samples of 50 seeds on three sheets of germitest paper moistened with distilled water, in a proportion of 3 times the dry paper weight. Next, they were placed inside a germination chamber set at $25^{\circ} \mathrm{C}$. At the end of 8 days, the normal seedlings were accounted as proposed in Rules for Seed Testing (Brasil, 2009).

The first germination count was performed five days after the test setup, when the normal seedlings were considered. The field emergence was determined by directly counting the seedlings sprouted in the three central 3-meter lines of each plot, 28 days after sowing. This test delimited 2 meters from each end, and two lines on each side of the plot as borders. The results were expressed in percentage.

The fieldwork was conducted in plots of seven 7-meterlong lines, spaced $0.45 \mathrm{~m}$. Evaluations of both survival and productivity were performed. The survival was assessed seven days before harvest, when the final number of seedlings in the lines had been determined. The results were linked to those of field emergence, so that the survival percentage (\%) could be properly estimated. Regarding productivity, the useful area comprised three central 3-meter-long lines. The pods within these limits were manually picked, then mechanically threshed. The grains obtained from the process were cleaned, and then weighed. The weight of grains for each plot was transformed to $\mathrm{kg} \mathrm{ha}^{-1}$, and they had their moisture content adjusted to $13 \%$.

The resulting data were analyzed right after the treatments, and again 45 days afterward, considering each sowing time independently. The analysis of variation and a hypothesis test were applied to check the significance of the effects in a trifactorial mode: treatment type (control, conventional, and industrial) $\mathrm{x}$ seed size $(5.5$ and $6.5 \mathrm{~mm}) \mathrm{x}$ cultivar (Monsoy 5730 IPRO and Monsoy 5947 IPRO). The means were compared through the Tukey's test at a 5\% probability level, performed with the Sisvar software pack (Ferreira, 2014).

\section{Results and Discussion}

The results of moisture content (Table 1) showed no interaction among the treatments. The seed size assessed right after the treatments, in its turn, produced distinct values: the 5.5-millimeter seeds presented a moisture content of $11.8 \%$, while the 6.5 -millimeter ones displayed $11.5 \%$. Such outcome might be due to the difference in weight that is related to size, once the same dosage of slurry was used in all cases. The little numeric difference is connected to the low coefficient of variation $(0.7 \%)$, which produced a least significant difference of $0.048 \%$ among the treatments. It is worth remarking that the small variations in moisture content did not impact the physiological quality of the seeds, because values below $12 \%$ (w.b.) tend to keep their quality at its highest, thus being recommended for preserving the vigor of soybean seeds (Smaniotto et al., 2014).

In the evaluation conducted 45 days after the treatment, the moisture content of seeds with $5.5 \mathrm{~mm}$ was lower than that of seeds sized $6.6 \mathrm{~mm}$. This result diverged from what was observed in the assessments performed right after the treatment application, and it is probably related to the uncontrolled conditions of the storage environment.

A difference in the moisture content was also noticed between the cultivars, probably due to the moisture content they held before the trials. The cultivar Monsoy 5730 IPRO presented a $12.4 \%$ moisture content right after the treatment, against $10.9 \%$ of the cultivar Monsoy 5947 IPRO (a difference of $1.5 \%$ ). The moisture content measured 45 days after the treatment stayed below $12 \%$ in both varieties, but the cultivar Monsoy 5730 IPRO continued to present the highest value,

Table 1. Soybean seed moisture content (\%) assessed at two distinct times (right after the treatment application and 45 days afterward), considering the control (untreated), conventional, and industrial treatments; the cultivars Monsoy 5730 IPRO and Monsoy 5947 IPRO; and the grain sizes of 5.5 and $6.5 \mathrm{~mm}$.

\begin{tabular}{lcc}
\hline & $\begin{array}{c}\text { Right after the } \\
\text { treatment }\end{array}$ & $\begin{array}{c}\text { 45 days after the } \\
\text { treatment }\end{array}$ \\
\hline 5.5 & $11.8 \mathrm{a}$ & $9.8 \mathrm{~b}$ \\
6.5 & $11.5 \mathrm{~b}$ & $10.0 \mathrm{a}$ \\
\hline Control & $11.5 \mathrm{c}$ & $9.9 \mathrm{a}$ \\
Conventional & $11.6 \mathrm{~b}$ & $9.9 \mathrm{a}$ \\
Industrial & $11.8 \mathrm{a}$ & $9.7 \mathrm{~b}$ \\
\hline Monsoy 5730 IPRO & $12.4 \mathrm{a}$ & $10.0 \mathrm{a}$ \\
Monsoy 5947 IPRO & $10.9 \mathrm{~b}$ & $9.8 \mathrm{~b}$ \\
\hline Mean & 11.66 & 9.89 \\
C.V. & 0.70 & 1.9 \\
\hline
\end{tabular}

*Means followed by the same letter, in the column, do not differ according to the Tukey's test, at a $5 \%$ probability error. 
although the gap between them ultimately reduced to $0.2 \%$.

By the 45th day after treatment, the moisture content had reduced in approximately $2 \%$ in both cases. Seed water loss generally occurs due to the hygroscopic nature of the grains, which causes them to attempt to establish an equilibrium with the surroundings. Figure 1 contains data on the relative air humidity variations during the 2016/2017 harvest, which explain the seed moisture content reduction throughout storage, until the second evaluation time, when relative humidity was estimated in about $60 \%$.

An interaction was noticed in seed coating (Table 2). In general, the industrial treatment produced better coated seeds, in contrast with the conventional method. Bays et al. (2007) found similar result, and also verified that a polymer application provides better adherence, distribution, and coloration to the treatments, without compromising the overall performance of the seeds.

Also, within the conventional treatment, there were differences between the seed sizes within the cultivars. In the cultivar Monsoy 5730 IPRO, the 5.5-millimeter seeds were better coated than the larger ones. On the other hand, considering the cultivar Monsoy 5947 IPRO, the 6.5-millimeter seeds received a better coating. Such results corroborate the findings of Ludwig et al. (2011a) and reaffirm the need for conducting conventional treatments with greater circumspection.

Regarding the seed quality evaluation, no significant effects were observed in the interactions. They were however noticed in the treatments. The analyses of germination and

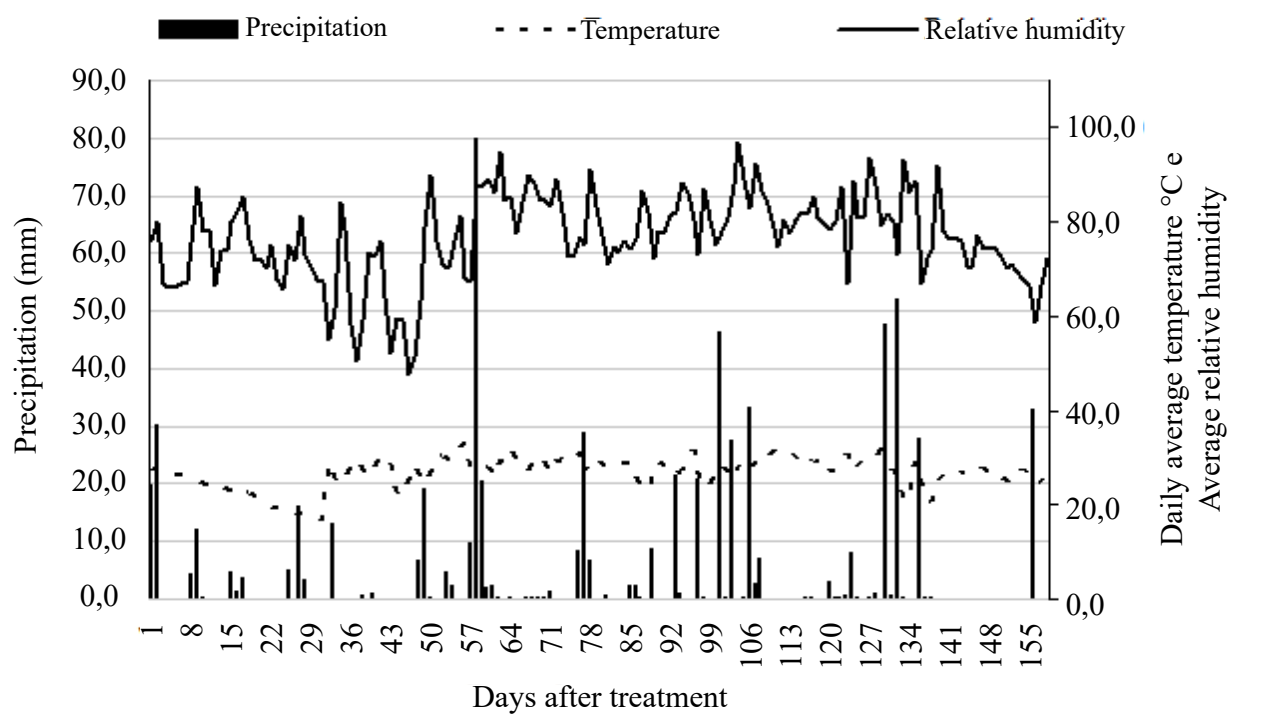

Figure 1. Precipitation (mm), relative humidity $(\%)$, and daily average temperature $\left({ }^{\circ} \mathrm{C}\right)$ during the $2016 / 2017$ harvest.

Table 2. Soybean seed coating performed according to the conventional and industrial treatments (two forms of each), using the cultivars Monsoy 5730 IPRO and Monsoy 5947 IPRO, with grains sized 5.5 and $6.5 \mathrm{~mm}$.

\begin{tabular}{|c|c|c|c|c|}
\hline & \multicolumn{2}{|c|}{ Monsoy 5730 IPRO } & \multicolumn{2}{|c|}{ Monsoy 5947 IPRO } \\
\hline & 5.5 & 6.5 & 5.5 & 6.5 \\
\hline Conventional & $7.0 \mathrm{bA}$ & $6.4 \mathrm{bB}$ & $6.7 \mathrm{bA}$ & $6.7 \mathrm{bA}$ \\
\hline \multirow[t]{3}{*}{ Industrial } & $9.8 \mathrm{aA}$ & $10 \mathrm{aA}$ & $9.8 \mathrm{aA}$ & $9.9 \mathrm{aA}$ \\
\hline & \multicolumn{2}{|c|}{5.5} & \multicolumn{2}{|c|}{6.5} \\
\hline & Monsoy 5730 IPRO & Monsoy 5947 IPRC & Monsoy 5730 IPRO & Monsoy 5947 IPRO \\
\hline Conventional & $7.0 \mathrm{bA}$ & $6.7 \mathrm{bB}$ & $6.4 \mathrm{bB}$ & $6.7 \mathrm{bA}$ \\
\hline Industrial & $9.8 \mathrm{aA}$ & $9.8 \mathrm{aA}$ & $10 \mathrm{aA}$ & $9.9 \mathrm{aA}$ \\
\hline Mean & \multicolumn{4}{|c|}{8.3} \\
\hline C.V. & \multicolumn{4}{|c|}{2.37} \\
\hline
\end{tabular}

*Means followed by the same lowercase letter, in the column, or uppercase letter, in the line, do not differ according to the Tukey's test, at a $5 \%$ probability error. 
first count produced superior results in the control treatment, at both experimental times (Table 3). The decrease in these two parameters, after a fungicide or insecticide application, was also verified by Bays et al. (2007) and Ludwig et al. (2011b). They proved that the addition of a fungicide caused a significant reduction in germination, probably due to the impact of the active ingredients. When present at high concentrations in the germination paper, these compounds usually have a phytotoxic effect on seeds. As a further remark, Grisi et al. (2009) affirmed that seeds with already high germination rates generally do not get any additional benefit from seed treatments.

The results from the field emergence test (Table 3) diverged from those of germination and first count. In both evaluation occasions, the highest emergence values were obtained when the seeds were treated, regardless of the application method. Treated seeds are protected against biotic factors that can lower the sprouting of seedlings, such as fungi and insects (Conceição et al., 2014). Pereira et al. (2009) also observed that treated seeds displayed a germination rate significantly higher than that of untreated ones, possibly due to the protective effect of the chemicals in use.

The field emergence of the industrially treated seeds marked $77.2 \%$ and $81.7 \%$, considering the evaluations carried out immediately after the processing, and 45 days later, respectively. These results are $10 \%$ and $8 \%$ higher than those produced by the control treatment. The conventional seed treatment, in its turn, produced values $6 \%$ and $8 \%$ more significant than the control ones in the first trial, and after the 45-day storage, respectively. These results evidenced the importance of using products to assure the proper emergence of the culture, so that the adequate plant population is achieved.
Nowadays, it is common sense that each cultivar requires a specific population size, and once this is not attained, grain yield is usually compromised. In this sense, the application of the products diminishes the negative effects of plagues and diseases, thus guaranteeing an adequate initial establishment of the culture, and consequently favoring higher productivity.

Regarding the physiologic quality of the cultivars, in the first evaluation time, Monsoy 5730 IPRO showed results of germination, first count, and emergence less prominent than those of Monsoy 5947 IPRO. Such outcomes are associated with the intrinsic characteristics of each variety. As clarified by Marcos-Filho et al. (2009), soybean cultivars that are significantly different as for their physiological potential also have distinct performance in the field. Therefore, this aspect is presumably important, taking into account that high-quality lots tend to present better productivity.

The importance of field emergence was gauged via the survival rate of the plants (Table 4). In the first sowing time, no difference was noticed between the treatment methods, but both produced a plant stand superior to the control. However, after the 45-day storage, the industrially treated seeds presented $8 \%$ and $19 \%$ more surviving plants than the conventional and control treatments, respectively. Furthermore, all three treatments differed from each other, with the industrial one providing the highest survival rate.

These results reinforce the importance of the industrial treatment for protecting seeds during storage. The conventionally treated seeds also showed a percentage of survival $10 \%$ higher than the untreated ones. The survival values are to be considered once they reflect the plant population maintenance, which possibly affects the productivity of a whole culture.

Table 3. Values (\%) of germination (G), first count (FC), and field emergence on the $28^{\text {th }}$ day (FE) of soybean seeds, assessed at two distinct times (right after the treatment application and 45 days afterward), considering the control (untreated), conventional, and industrial treatments; the cultivars Monsoy 5730 IPRO and Monsoy 5947 IPRO; and the grain sizes of 5.5 and $6.5 \mathrm{~mm}$.

\begin{tabular}{|c|c|c|c|c|c|c|}
\hline & \multicolumn{3}{|c|}{ Right after the treatment } & \multicolumn{3}{|c|}{45 days after the treatment } \\
\hline & $\mathrm{G}$ & $\mathrm{PC}$ & $\mathrm{EC}$ & $\mathrm{G}$ & $\mathrm{PC}$ & $\mathrm{EC}$ \\
\hline Control & $81 \mathrm{a}$ & $69.1 \mathrm{a}$ & $67.1 \mathrm{~b}$ & $64 \mathrm{a}$ & $36.8 \mathrm{a}$ & $73.3 \mathrm{~b}$ \\
\hline Conventional & $72 \mathrm{~b}$ & $58.6 \mathrm{~b}$ & $73.6 \mathrm{a}$ & $57 \mathrm{~b}$ & $32.1 \mathrm{~b}$ & $81.8 \mathrm{a}$ \\
\hline Industrial & $73 \mathrm{~b}$ & $58.7 \mathrm{~b}$ & $77.2 \mathrm{a}$ & $51 \mathrm{c}$ & $28.5 \mathrm{~b}$ & $81.7 \mathrm{a}$ \\
\hline Monsoy 5730 IPRO & $70 \mathrm{~b}$ & $54.8 \mathrm{~b}$ & $66.0 \mathrm{~b}$ & $58 \mathrm{a}$ & $32.5 \mathrm{a}$ & $80.0 \mathrm{a}$ \\
\hline Monsoy 5947 IPRO & $81 \mathrm{a}$ & $65.5 \mathrm{a}$ & $79.3 \mathrm{a}$ & $58 \mathrm{a}$ & $32.4 \mathrm{a}$ & $78.6 \mathrm{a}$ \\
\hline Mean & 75 & 62.2 & 72.1 & 58 & 32.5 & 79.3 \\
\hline C.V. & 5.64 & 7.3 & 10.94 & 14.84 & 21.52 & 7.17 \\
\hline
\end{tabular}

*Means followed by the same letter do not differ, according to the Tukey's test, at a 5\% probability error. 
Table 4. Values of productivity $\left(\mathrm{kg} \cdot \mathrm{ha}^{-1}\right)$ and plant survival rate (\%) of soybean seeds, assessed at two distinct times (right after the treatment application and 45 days afterward), considering the control (untreated), conventional, and industrial treatments; the cultivars Monsoy 5730 IPRO and Monsoy 5947 IPRO; and the grain sizes of 5.5 and $6.5 \mathrm{~mm}$.

\begin{tabular}{lcccc}
\hline & \multicolumn{2}{c}{ Right after the treatment } & \multicolumn{2}{c}{45 days after the treatment } \\
\cline { 2 - 5 } & Productivity & Survival & Productivity & Survival \\
\hline Control & $3586 \mathrm{a}$ & $67.1 \mathrm{~b}$ & $3584 \mathrm{~b}$ & $62.8 \mathrm{c}$ \\
Conventional & $3327 \mathrm{~b}$ & $73.7 \mathrm{a}$ & $3519 \mathrm{~b}$ & $73.5 \mathrm{~b}$ \\
Industrial & $3730 \mathrm{a}$ & $77.2 \mathrm{a}$ & $3813 \mathrm{a}$ & $81.7 \mathrm{a}$ \\
\hline Monsoy 5730 IPRO & $3429 \mathrm{~b}$ & $66.0 \mathrm{~b}$ & $3637 \mathrm{a}$ & $69.1 \mathrm{~b}$ \\
Monsoy 5947 IPRO & $3667 \mathrm{a}$ & $79.3 \mathrm{a}$ & $3641 \mathrm{a}$ & $76.3 \mathrm{a}$ \\
\hline \multicolumn{1}{c}{ Mean } & 3547 & 72.6 & 3639 & 72.1 \\
\multicolumn{1}{c}{ C.V. } & 8.54 & 10.94 & 7.9 & 12 \\
\hline
\end{tabular}

* Means followed by the same letter, in the column, do not differ according to the Tukey's test at a 5\% probability error.

The evaluation of survival considering the cultivars showed values of $79.3 \%$, for the Monsoy 5947 IPRO, and $66 \%$, for the Monsoy 5730 IPRO, implying in a $13 \%$ difference between them. In the analysis 45 days after the treatment, the cultivar Monsoy 5947 IPRO once again had the highest rate, which this time marked $7 \%$ more than that of Monsoy 5730 IPRO.

The productivity assessed in the first trial showed that the industrial treatment yielded $3730 \mathrm{~kg} \cdot \mathrm{ha}^{-1}$, thus being superior to the conventional one, but not differing from the control treatment. When productivity was considered 45 days after the application of the products, a value of $3813 \mathrm{~kg} \cdot \mathrm{ha}^{-1}$ was obtained for the industrial treatment, which was superior to the others. Nevertheless, the productivity found in the control (3584 kg.ha-1) and conventional (3519 kg.ha- ${ }^{-1}$ ) treatments statistically did not differ from one another.

Based on these findings, it is possible to infer that the industrial treatment allows an efficient application of several products at the exact dose, due to the generally more modern and effective dispensers. The same is not always replicable in farm conditions, where techniques commonly used do not always produce an ideal coating of seeds (Ludwig, 2017b).

Therefore, seed treatments play a crucial part in preventing diseases and plague attacks in early phases of crops, protecting seed vigor, and favoring the establishment of the seedlings (Nunes, 2016). However, the application has to be done correctly, in order to guarantee the beneficial effects of the products. Balardin et al. (2011) emphasize that the treatment of soybean seeds generates positive responses in the plants, increasing their tolerance to water stress and boosting the grain yield of the culture.

The cultivar Monsoy 5730 IPRO had inferior productivity compared to Monsoy 5947 IPRO, in the evaluation following the treatment. However, 45 days afterward, no difference was reported between them. These results correlate with the survival of the varieties, for which the difference was respectively of $13 \%$ and $7 \%$ in the first evaluation, and after storage for 45 days. In this sense, soybean cultures have plasticity, which helps to keep the productivity even when plant population varies slightly.

\section{Conclusions}

Seed size has no influence on the productivity or quality of soybean seeds subjected to different chemical treatments.

The industrial treatment produces a better coating to the seeds. Additionally, it results in a higher field seedling emergence rate and provides a higher grain yield.

\section{References}

ABRASEM. Associação Brasileira de Sementes e Mudas. Guia Abrasem de Boas Práticas de Tratamento de Sementes. www. abrasem.com.br/wp-content/uploads/2014/12/Guia-TSI-completo. pdf $>$. Accessed on April 15 $5^{\text {th }}, 2018$.

BALARDIN, R.S.; SILVA, F.D.L.; DEBONA, D.; CORTE, G.D.; FAVERA. D.D.; TORMEN, N.R. Tratamento de sementes com fungicidas e inseticidas como redutores dos efeitos do estresse hídrico em plantas de soja. Ciência Rural, v.41, n.7, 2011. http:// www.scielo.br/pdf/cr/v41n7/a5711cr4207.pdf

BAYS, R.; BAUDET, L.; HENNING, A.A.; FILHO, O.L. Recobrimento de sementes de soja com micronutriente, fungicida e polímero. Revista Brasileira de Sementes, v.29, n.2, p.60-67, 2007. http://www.scielo.br/pdf/rbs/v29n2/v29n2a09.pdf 
BRASIL. Ministério da Agricultura, Pecuária e Abastecimento. Regras para análise de sementes. Ministério da Agricultura, Pecuária e Abastecimento. Secretaria de Defesa Agropecuária. Brasília: MAPA/ACS, 2009. 395p.

BURRIS, J. Film coating recovery quality rating scale. Ames, IA: Seed Science Center, Iowa State University, s.d. 1p.

BURSSOLARO, I.; ZELIN, E.; SIMONETTI, A.P.M.M. Aplicação de silício no controle de percevejos e produtividade da soja. Cultivando o Saber, v.4, n.3, p.9-19, 2011. https://www.fag.edu.br/ upload/revista/cultivando_o_saber/592dc07950c20.pdf

CONAB. Companhia Nacional de Abastecimento. Acompanhamento da Safra Brasileira: sexto levantamento de grãos safra 2017/2018. www. conab.gov.br/OlalaCMS/uploads/arquivos/18_03_13_14_15_33_ grao_marco_2018.pdf Accessed on March 30 ${ }^{\text {th }}, 2018$.

CONCEIÇÃO, G.M.; BARBIERI, A.P.P.; LÚCIO, A.D.; MARTIN, T.N.; MERTZ, L.M.; MATTIONI, N.M.; LORENTZ, L.H. Desempenho de plântulas e produtividade de soja submetida a diferentes tratamentos químicos nas sementes. Bioscience Journal, v.30, n.6, p.1711-1720, 2014. http://www.seer.ufu.br/index.php/ biosciencejournal/article/view/22024/15608

EMBRAPA. Sistema brasileiro de classificação de solos. Centro Nacional de Pesquisa de Solo. Brasília: Embrapa, 2013. 306p. http://server1.docfoc.com/uploads/Z2016/01/04/dPYPGwIY1r/ df34f855c7edc99a4cb40f0a5191519d.pdf Accessed on November $5^{\text {th }}, 2016$.

FERREIRA, D.F. SISVAR: A guide for its bootstrap procedures in multiple comparisons. Ciência e Agrotecnologia, v.38, n.4, p.278286, 2014. http://dx.doi.org/10.1590/S1413-70542014000200001

FREIBERG, J.A.; LUDWIG, M.P.; DECARLI, L.; GIROTTO, E.; NAVARINI, L. Physiological quality, initial establishment and yield of wheat according to the seed treatment method. Pesquisa Agropecuária Tropical, v.47, n.4, p.448-455, 2017. https://dx.doi. org/10.1590/1983-40632017v4749214

GRISI, P.U.; SANTOS. C.M.; FERNANDES. J.J.; SÁ JÚNIOR, A. Quality of sunflower seeds treated with fungicide and inseticide. Bioscience Journal, v.25, n.4, p.28-36, 2009. http://www.seer.ufu.br/ index.php/biosciencejournal/article/viewArticle/6948

LUDWIG, M.P.; FILHO, O.A.L.; BAUDET, L.; DUTRA, L.M.C.; AVELAR, S.A.G.; CRIZEL, R.L.; OLIVEIRA, S. Eficiência do recobrimento de sementes de soja em equipamento com sistema de aspersão. Ciência Rural, v.41, n.4, 2011a. http://www.scielo.br/pdf/ $\mathrm{cr} / \mathrm{v} 41 \mathrm{n} 4 / \mathrm{a} 911 \mathrm{cr} 3248 . \mathrm{pdf}$
LUDWIG, M.P.; FILHO, O.A.L.; BAUDET, L.; DUTRA, L.M.C.; AVELAR, S.A.G.; CRIZEL, R.L. Qualidade de sementes de soja armazenadas após recobrimento com aminoácido, polímero, fungicida e inseticida. Revista Brasileira de Sementes, v.33, n.2, p.395-406, 2011b. http://www.scielo.br/pdf/rbs/v33n3/02.pdf

LUDWIG, M.P.; OLIVEIRA, S.; AVELAR, S.A.G.; ROSA, M.P.; FILHO, O.A.L.; CRIZEL, R.L. Armazenamento de sementes de soja tratada e seu efeito no desempenho de plântulas. Tecnologia \& Ciência Agropecuária, v.9, n.1, p.51-56, 2015. http://revistatca.pb.gov.br/ edicoes/volume-09-2015/volume-9-numero-1-marco-2015/tca9110.pdf

LUDWIG, M.P. O Tratamento e o tamanho das sementes de soja. Revista Seed News, v.20, n.2, p.10-13, 2017a. https://seednews.com. br/edicoes/artigo/38-o-tratamento-e-o-tamanho-da-semente-desoja-edicao-marco-2017

LUDWIG, M.P. Tratamento de Sementes: Profissionalização. Revista Seed News, v.21, n.4, p.10-12, 2017b. https://seednews.com. br/edicoes/artigo/267-tratamento-de-sementes:-profissionalizacaoedicao-julho-2017

MARCOS-FILHO, J.; KIKUTI, A.L.P.; LIMA, L.B. Métodos para avaliação do vigor de sementes de soja, incluindo a análise computadorizada de imagens. Revista Brasileira de Sementes, v.31, n.1, p.102-112, 2009. http://www.scielo.br/pdf/rbs/v31n1/a12v31n1.pdf

MORENO, J.A. Clima do Rio Grande do Sul. Porto Alegre: Secretaria de Agricultura. Diretoria de terras e colonização, Seção de Geografia, 1961. 43p.

NUNES, J.C.S. Tratamento de sementes de soja como um processo industrial no Brasil. Revista Seed News, v.20, n.1, p.26-32, 2016. https://seednews.com.br/edicoes/artigo/334-tratamento-de-sementesde-soja-como-um-processo-industrial-no-brasil-edicao-janeiro-2016

PEREIRA, C.E.; OLIVEIRA, J.A.; ROSA, M.C.M.; OLIVEIRA, G.E.; NETO, J.C. Tratamento fungicida de sementes de soja inoculadas com Colletotrichum truncatum. Ciência Rural, v.39, n.9, p.2390-2395, 2009. http://www.scielo.br/pdf/cr/v39n9/a387cr1431.pdf

PESKE, S.T.; LABBÉ, L.M.B. Beneficiamento de sementes. In: PESKE, S.T.; VILLELA, F.A.; MENEGHELLO, G.E. (Eds.) Sementes: fundamentos cientificos e tecnológicos. Pelotas: Editora Universitária UFPel, 2012. p.424-480.

SMANIOTTO, T.A.S.; RESENDE, O.; MARÇAL, K.A.F.; OLIVEIRA, D.E.C.; SIMON, G.A. Qualidade fisiológica das sementes de soja armazenadas em diferentes condições. Revista Brasileira de Engenharia Agrícola e Ambiental, v.18, n.4, p.446-453, 2014. http:// www.agriambi.com.br/revista/v18n04/v18n04a13.pdf 